\title{
PENANGANAN IKAN CAKALANG OLEH NELAYAN POLE AND LINE
}

\author{
Christina Litaay ${ }^{1^{*}}$, Sugeng Hari Wisudo ${ }^{2}$, Hairati Arfah $^{3}$ \\ ${ }^{1}$ Pusat Penelitian Teknologi Tepat Guna, LIPI Subang, Jawa Barat \\ Jalan KS. Tubun Nomor 5, Cigadung, Subang Jawa Barat 41213 \\ ${ }^{2}$ Departemen Pemanfaatan Sumberdaya Laut, FPIK-IPB, Bogor, Jawa Barat \\ ${ }^{3}$ Pusat Penelitian Laut Dalam, LIPI Ambon, Maluku \\ ${ }^{*}$ Korespondensi: christina_litaay@yahoo.com
}

Diterima: 27 September 2019/ Disetujui: 27 April 2020

Cara sitasi: Litaay C, Wisudo SH, Arfah H. 2020. Penanganan ikan cakalang oleh nelayan pole and line. Jurnal Pengolahan Hasil Perikanan Indonesia. 23(1): 112-121.

\begin{abstract}
Abstrak
Penanganan ikan segar merupakan bagian penting dari rantai pasokan industri perikanan. Penelitian ini bertujuan untuk menganalisis penanganan dan penyimpanan ikan cakalang. Penelitian ini difokuskan pada kegiatan penangkapan pole and line untuk ikan cakalang di perairan Seram. Penelitian ini menggunakan teknik observasi lapangan dan uji organoleptik. Proses penanganan ikan di kapal menggunakan es balok dan air laut yang didinginkan terdiri atas penyortiran, pencucian, dan penirisan namun belum optimal. Fasilitas dan infrastruktur untuk penanganan ikan di pusat pendaratan juga tidak memadai, tidak ada tempat untuk melakukan beberapa pekerjaan yaitu penyortiran, pencucian, dan penirisan. Nilai organoleptik menurun dari 9,00 pada 0 jam menjadi 8,68 pada 12 jam, ketika ikan tiba di pusat pendaratan ikan. Peningkatan penanganan cakalang di kapal dan di pusat pendaratan ikan diperlukan untuk menjaga kualitas ikan dan mencegah kerusakan ikan.
\end{abstract}

Kata kunci: ikan cakalang, organoleptik, penanganan, penyimpanan, pole and line

\section{HANDLING SYSTEM OF SKIPJACK TUNA BY POLE AND LINE FISHERMEN}

Abstract

Fresh fish handling is an important part of fisheries industry supply chain. This research was aimed to analyze skipjack handling and storage systems. The research was focused on pole and line fishing activities for skipjack tuna in the Seram waters. The research used field observation technique and organoleptic test to examine the handling techniques. The process of fish handling used ice block and chilled seawater, however, the sortation, washing, and draining steps were not well-conducted. The facilities and infrastructure for fish handling at the landing center were also inadequate; no available place to do some works such as sortation, washing and draining. Organoleptic value were decreased from 9.00 at 0 hours to 8.68 at 12 hours, when the fish arrived at the fish landing center. Improvement of the handling of skipjack on board and at the fish landing center is needed to maintain the quality of fish and prevent the deterioration of fish.

Keywords: handling, organoleptic, pole and line, skipjack fish, storage

\section{PENDAHULUAN}

Ikan cakalang merupakan jenis sumber daya perikanan yang dimanfaatkan sebagai konsumsi lokal maupun komoditi ekspor, sehingga ikan ini memiliki nilai ekonomis yang tinggi (Tumonda et al. 2017). Alat tangkap yang sering digunakan untuk menangkap ikan cakalang di Indonesia adalah pole and line. Alat tangkap pole and line berupa pancing, sehingga sangat selektif dan efektif dalam menangkap ikan cakalang serta tidak merusak lingkungan sekitar saat proses penangkapan. Proses penangkapan tuna cakalang, sangat lebih baik jika menggunakan alat tangkap pole and line (WWF 2005). Selain itu alat tangkap pancing dan bubu lebih rendah tingkat kehilangan dibandingkan jaring insang dan jaring lingkar (Akande dan Diei-Ouadi 2010).

Produksi ikan di Indonesia lebih banyak dihasilkan melalui usaha perikanan pole and 
line dalam skala kecil dan tradisional. Kondisi ini disesuaikan dengan belum memadainya fasilitas dan teknologi yang sederhana. Nelayan belum memperhatikan pentingnya kesiapan bahan dan alat dalam menunjang proses penanganan ikan di atas kapal sampai pusat pendaratan ikan. Proses penangkapan yang dilakukan oleh nelayan dapat bersifat one day fishing maupun tidak tergantung dari banyaknya umpan yang tersedia. Masalah lain yang mendasar juga adalah permintaan hasil tangkapan ikan cakalang yang meningkat dengan harga jual tinggi, mengakibatkan nelayan berlomba-lomba untuk mendapatkan tangkapan sebanyak mungkin agar keuntungan lebih banyak. Namun disisi lain kurangnya pengetahuan tentang penangkapan dan penanganan ikan secara baik menyebabkan tangkapan berjumlah banyak, tetapi berkualitas rendah dengan harga jual minimal. Hal ini tidak hanya merugikan secara ekonomi, tetapi juga berkontribusi pada pemborosan sumber daya.

Beberapa penelitian terkait penanganan ikan dan kesegaran telah dilakukan di antaranya adalah penanganan ikan cakalang di atas kapal KM. Cakalang Pulau Morotai menunjukkan bahwa dalam kurun waktu penanganan ikan selama kurang dari 2 jam terjadi penurunan mutu kesegaran ikan sebesar 1,96\%, sedangkan jangka waktu 5-6 jam, kemunduran sebesar 4,49\%. Secara umum ikan yang ditangkap mulai di kapal sampai di TPI mengalami penurunan mutu sebesar 29,37\% dengan nilai mutu organoleptik ikan 7 (Deni 2015). Penanganan terhadap ikan kembung menggunakan es curai pada rasio es dan ikan 1:5 mengalami tingkat penurunan nilai organoleptik sangat cepat dibandingkan rasio es dan ikan 1:1 dan 1:3 (Susanto et al. 2011). Tahapan dalam menangani ikan setelah ditangkap adalah ikan segera dimatikan dengan memukul bagian kepala ikan, selanjutnya proses pencucian ikan dan penyimpanan ikan dalam palka dengan rasio es dan ikan 1:1 (Widiastuti dan Putro 2010). Olodosu et al. (2011) melaporkan bahwa setelah tertangkap ikan sering dibiarkan pada suhu kamar dalam waktu lama yang mengakibatkan penurunan kualitas dan pembusukan ikan pasca panen.
Metusalach et al. (2014) menjelaskan bahwa terdapat beberapa faktor yang memengaruhi terjadinya penurunan mutu dan kerusakan ikan setelah ikan ditangkap antara lain kurang memadainya fasilitas, proses penanganan ikan yang belum sesuai prosedur, dan proses penangkapan ikan. Selain itu mutu ikan sangat dipengaruhi oleh proses penangkapan yang berhubungan langsung dengan cara ikan mati. Studi Akande dan Diei-Ouadi (2010) menunjukkan bahwa di negara-negara berkembang, telah terjadi kehilangan pasca panen sebesar 20-40\% dari total produksi, dan kehilangan kualitas sebesar 70\%.

Pemecahan masalah perikanan sebagaimana digambarkan di atas, tidak dapat dilakukan sebagian saja tetapi harus menyeluruh dan secara bersamaan untuk menghasilkan penanganan yang tepat, maka perlu adanya pengembangan teknik penanganan ikan cakalang dengan benar. Penerapan teknologi penanganan yang baik sesaat setelah ikan ditangkap sampai ikan di pusat pendaratan ikan sebagai panduan proses penanganan ikan adalah solusi pemecahan yang akan dilakukan melalui penelitian ini.

\section{METODE PENELITIAN Bahan dan Alat}

Bahan dalam penelitian ini adalah kuisioner, score sheet, sampel ikan cakalang (Katsuwonus pelamis) sebanyak 9 ekor dengan berat berkisar 2,2-4,8 kg, es balok dan air laut yang didinginkan. Alat yang digunakan dalam penelitian adalah palka pendingin, alat ganco, ember, pemukul es balok, alat tulis, dan kamera digital.

\section{Prosedur Penelitian}

Penelitian ini dilakukan untuk mengamati sistem penanganan ikan cakalang dari mulai ditangkap, penanganan di atas kapal hingga didaratkan serta mutu ikan secara organoleptik. Penelitian ini bersifat deskriptif dengan cara observasi dan wawancara berdasarkan studi kasus teknik penanganan ikan oleh nelayan pole and line sesaat setelah ditangkap sampai di pusat pendaratan ikan. Penelitian aspek penanganan ikan cakalang dibatasi pada penanganan sesaat setelah ikan di atas kapal sampai pada lokasi pendaratan 
ikan. Wawancara dilakukan pada 25 nelayan yang merupakan $\mathrm{ABK}$ pada kapal pole and line. Pengambilan data primer dilakukan melalui score sheet dan penelitian kesegaran ikan mulai di atas kapal sejak ikan mati sampai di tempat pendaratan ikan. Selain itu juga dilakukan penelitian terkait cara perlakuan hasil tangkapan antara lain penerapan pencucian, sortasi dan penirisan hasil tangkapan, penggunaan es serta metode penyimpanan hasil tangkapan di palka pendinginan mulai dari di atas kapal sampai di pusat pendaratan ikan. Data sekunder berasal dari instansi pemerintah dan penelitian yang telah dipublikasi.

\section{Analisis Data}

Analisis data secara deskriptif, dengan cara mendeskripsikan teknik penanganan ikan cakalang sesaat setelah di atas kapal sampai di pusat pendaratan ikan. Uji organoleptik ikan segar mengacu pada BSN (2006). Pengamatan dilakukan terhadap penanganan ikan dengan variasi metode pendinginan, selanjutnya proses pengujian nilai organoleptik (mata, lendir, insang, daging, bau, dan tekstur). Metode pengujian organoleptik scoring test menggunakan skala angka dengan rentang nilai 1-9, dan syarat nilai mutu organoleptik adalah minimum 7,0. Jika hasil pengujian produk perikanan memiliki nilai $<7$ maka produk tersebut memiliki kualitas ikan yang rendah dan dinyatakan tidak lulus standar. Nilai organoleptik 7 merupakan batas penerimaan konsumen dengan tanda kualitas ikan sebagai berikut : spesifikasi mata (agak keruh, bola mata rata, pupil agak keabu-abuan, kornea agak keruh), insang (warna merah agak kusam, tanpa lendir), lendir permukaan badan (lapisan lendir mulai agak keruh, warna agak putih, kurang transparan), daging (sayatan daging sedikit kurang cemerlang, spesifik jenis, tidak ada pemerahan sepanjang tulang belakang, dinding perut daging utuh), bau (netral), dan tekstur (agak padat, agak elastis bila ditekan dengan jari, sulit menyobek daging dari tulang belakang).

\section{HASIL DAN PEMBAHASAN}

Ikan cakalang merupakan komoditas ekspor, yang kualitas dan mutu ikan sangat tergantung pada teknik penanganan sesaat setelah ikan di atas kapal sampai di pusat pendaratan ikan. Beberapa hal penting yang perlu diperhatikan terkait keamanan dan mutu ikan antara lain operasi penangkapan ikan, teknik penanganan ikan baik di atas kapal maupun di pusat pendaratan ikan, dan teknik penyimpanan ikan dalam palka yang benar.

\section{Penanganan Ikan Cakalang di atas Kapal}

Berdasarkan hasil observasi lapangan, tahapan cara penanganan ikan di atas kapal (Figure 1) dijelaskan sebagai berikut:

a). Penangkapan ikan. Ikan yang tertangkap dibiarkan menggelepar di atas deck kapal sampai mati sendiri. Ikan yang menggelepargelepar menyebabkan ikan luka atau memar.

b). Sortasi. Proses sortasi pada hasil tangkapan dengan tidak dilakukan dengan benar. Ikan yang berbeda ukuran maupun jenis dimasukkan dalam palka secara bersamaan, dalam proses sortasi nelayan berkontak langsung dengan ikan.

c).Pencucian. Proses pencucian untuk membersihkan ikan dari darah tidak dilakukan dengan baik. Ikan yang tertangkap dan terkumpul di atas deck kapal sesekali disiram atau disemprot dengan air laut. Hal ini mengakibatkan ikan yang dimasukkan ke dalam palka penuh dengan cairan darah ikan. d). Penirisan. Ikan yang akan dimasukkan ke dalam palka tidak dilakukan penirisan, diangkat dan dijepit dengan jari sebanyak 2-5 ekor jika ikan berukuran besar dan $>8$ ekor jika ikan berukuran kecil.

e). Penyimpanan ikan. Proses pendinginan menggunakan es balok yang telah dihancurkan, dengan penyusunan ikan yang tidak teratur, berhimpit dan ikan dilempar ke dalam palka. Hal ini menyebabkan ikan cepat rusak. Penyimpanan ikan yang dilakukan belum memperhatikan sanitasi dan higienitas.

Penanganan ikan di atas kapal dilakukan setelah nelayan memastikan bahwa semua ikan sudah tertangkap, dengan kata lain waktu penanganan ikan disesuaikan dengan lamanya proses penangkapan. Ikan yang tertangkap dalam operasi penangkapan semakin banyak, maka kegiatan penanganan ikan di 


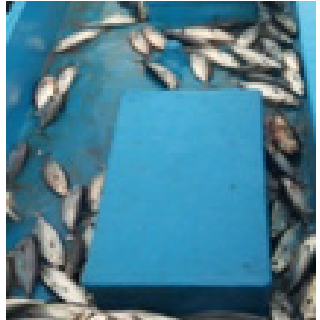

(a)

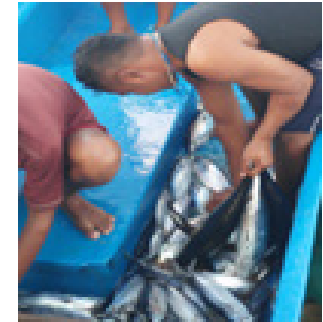

(b)

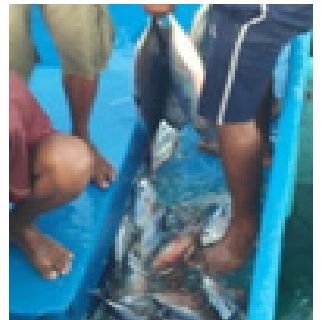

(c)

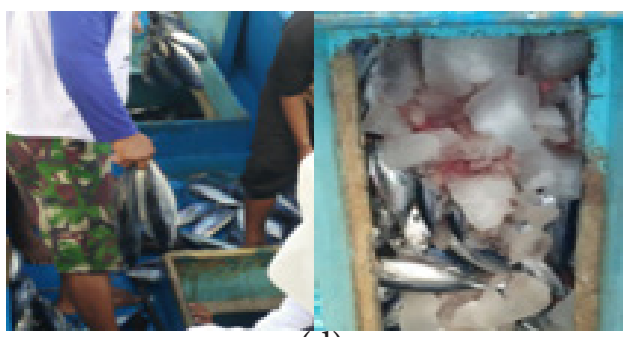

(d)

Figure 1 Fish handling on board: (a) fish were left to die; (b) fish sorting; (c) fish washing

(d) storage of fish in the hold

atas kapal juga akan terlambat. Jika operasi penangkapan masih berlangsung, maka ikan dibiarkan di atas dok kapal tanpa proses penanganan. Selama operasi penangkapan ikan berlangsung, ikan yang terkumpul di atas deck kapal disemprot dengan air laut untuk menghilangkan darah. Proses penanganan yang dilakukan di atas kapal masih tergolong sederhana berdasarkan pengalaman nelayan. Nelayan perlu memperhatikan kualitas ikan tetap dalam kondisi segar sampai di pusat pendaratan ikan.

Proses penanganan yang dilakukan oleh nelayan sesaat setelah ikan ditangkap antara lain pencucian, pensortiran dan penirisan tidak dilakukan dengan baik. Hal ini dapat mengakibatkan kemunduran mutu ikan. Penanganan ikan sesaat setelah ikan ditangkap sangat berpengaruh terhadap kualitas ikan hasil tangkapan. Starling dan Diver (2005) melaporkan bahwa faktorfaktor yang memengaruhi mutu ikan tuna terdiri dari faktor biologis (umur, spesies, tingkat kematangan seksual dan adanya penyakit) dan faktor non biologis (teknik penangkapan, penanganan, pendinginan, dan penyimpanan). Jika teknik penanganan ikan yang dilakukan baik, maka ikan akan memiliki kualitas yang baik dan harga jual yang tinggi. Berdasarkan pengamatan di lapangan, maka dapat digambarkan sistem penanganan ikan cakalang di atas kapal oleh nelayan (Figure 2).

Proses penyimpanan ikan pada palka pendinginan belum dilakukan sesuai prosedur. Nelayan tidak melakukan proses pensortiran hasil tangkapan sesuai ukuran, jenis ikan dan kualitas ikan. Penyimpanan ikan berdasarkan ukuran sangat penting karena ikan dengan ukuran kecil lebih cepat mengalami proses pembusukan dibandingkan ikan dengan ukuran besar. Kondisi ini disebabkan karena komposisi kimia daging ikan yang berbeda. Murniyati dan Sunarman (2000) menjelaskan bahwa daging ikan tuna memiliki komposisi kimia yang bervariasi tergantung ukuran dan jenis ikan, serta jenis kelamin, dan musim.

Penanganan pasca penangkapan adalah untuk menjaga kualitas hasil tangkapan (WWF 2015). Kru kapal harus menjaga kebersihan untuk menjaga kualitas ikan, pada saat ikan di ditaruh di atas geladak atau lantai kapal, ikan tidak terluka atau cacat saat dihentakkan atau dilempar, dan cara menjaga agar rantai dingin tidak putus sampai ke penampungan di darat atau sampai ditangan pembeli. Kualitas dan mutu yang baik dapat meningkatkan harga jual hasil tangkapan. Proses pemancingan yang dilakukan oleh nelayan berlangsung selama umpan masih tersedia, dan ikan yang tertangkap langsung dibersihkan dengan cara sesekali menyemprot ikan menggunakan air laut. Apabila ikan sudah dalam keadaan 


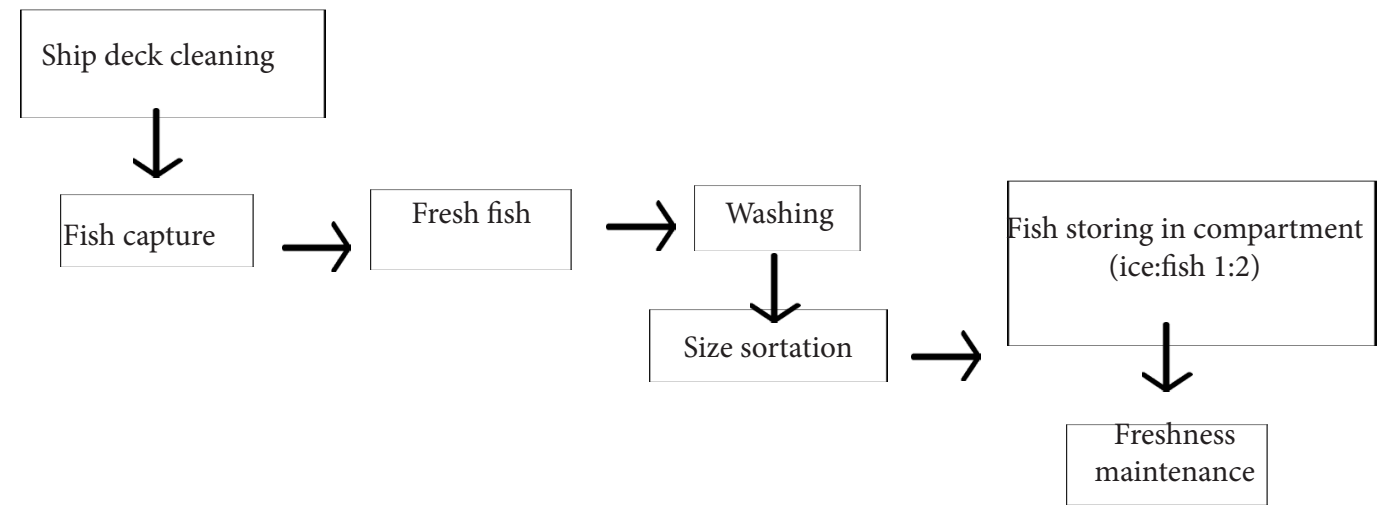

Figure 2 Fish handling flow by fishermen on board

bersih selanjutnya proses penyimpanan ikan dalam palka berisi es.

Proses penanganan yang dilakukan oleh nelayan belum sesuai dengan standar HACCP, seperti halnya proses pensortiran. Ikan yang mengalami cacat fisik seperti memar atau luka akibat mati menggelepar, masih ditempatkan dalam palka pendingin bersama ikan yang utuh. Nelayan tidak melakukan proses pensortiran dari segi kualitas antara ikan yang cacat fisik dan ikan yang utuh, ukuran ikan, dan jenis ikan yang ditangkap. Ikan yang mengalami cacat fisik akan cepat terjadi proses penurunan mutu akibat aktivitas bakteri, sehingga dengan mudah akan mengkontaminasi ikan yang utuh atau kualitas baik. Kondisi ini harus menjadi perhatian nelayan dan dihindari.

Wibowo dan Yunizal (1998) menjelaskan bahwa penanganan ikan di atas kapal yang tidak memiliki sarana palka penyimpanan ikan yang baik, memiliki tingkat kerusakan ikan sebesar 20-30\% sejak di atas kapal sampai di pusat pendaratan. Pengetahuan nelayan yang minim terkait penanganan ikan akan mengakibatkan penurunan tingkat kesegaran ikan setelah ikan ditangkap. Hal ini juga sangat berpengaruh pada proses pengolahan ikan selanjutnya. Akande dan Diei-Ouadi (2010) melaporkan bahwa di negara-negara berkembang, telah terjadi kehilangan pasca panen sebesar $20-40 \%$ dari total produksi, dan kehilangan kualitas sebesar 70\%. Menurut Quang (2005), sesaat setelah penangkapan ikan akan terjadi proses penurunan mutu sampai di konsumen.

Proses perbaikan untuk mencegah kemunduran ikan sehingga kesegaran dan kualitas ikan dapat dilihat pada Figure 3. Penanganan primer terkait pencucian, pensortiran dan penirisan perlu dilakukan, selain itu jumlah es dan lamanya waktu pendinginan perlu diperhatikan. Faktor perbandingan antara ikan dan es sangat menentukan kualitas ikan. Perbandingan 1:2 merupakan perbandingan penggunaan es dan banyaknya ikan dalam proses penanganan yang dilakukan nelayan. Perbandingan ini menyangkut suhu ikan yang ingin dicapai, suhu ikan harus tetap pada suhu $0^{\circ} \mathrm{C}$ sampai ikan berada di tangan konsumen. Apabila jumlah es terlalu sedikit, maka suhu tidak mampu mempertahankan tingkat kesegaran ikan dalam jangka waktu lama. Sedangkan apabila jumlah es terlalu banyak, maka bongkahan/pecahan es batu akan dapat merusak ikan. Menurut Widiastuti dan Putro (2010) tahapan dalam menangani ikan setelah ditangkap adalah ikan segera dimatikan dengan memukul bagian kepala ikan, selanjutnya proses pencucian ikan dan penyimpanan ikan dalam palka dengan rasio es dan ikan 1:1. Kebutuhan es sangat diperlukan selama proses pendinginan ikan diatas kapal sampai ikan di pusat pendaratan ikan. Rasio perbandingan ikan dan es $1: 1$ merupakan perbandingan yang ideal, yaitu ikan $1 \mathrm{~kg}$ harus sebanding dengan $1 \mathrm{~kg}$ es. Ikan yang baru ditangkap memiliki suhu $25^{\circ} \mathrm{C}$ dan proses penyimpanan ikan dalam palka perlu dipertahankan suhunya mendekati $0^{\circ} \mathrm{C}$ selama 12 jam mulai dari ikan ditangani di atas kapal sampai pusat pendaratan ikan, agar tingkat kesegaran ikan tetap terjaga dan 


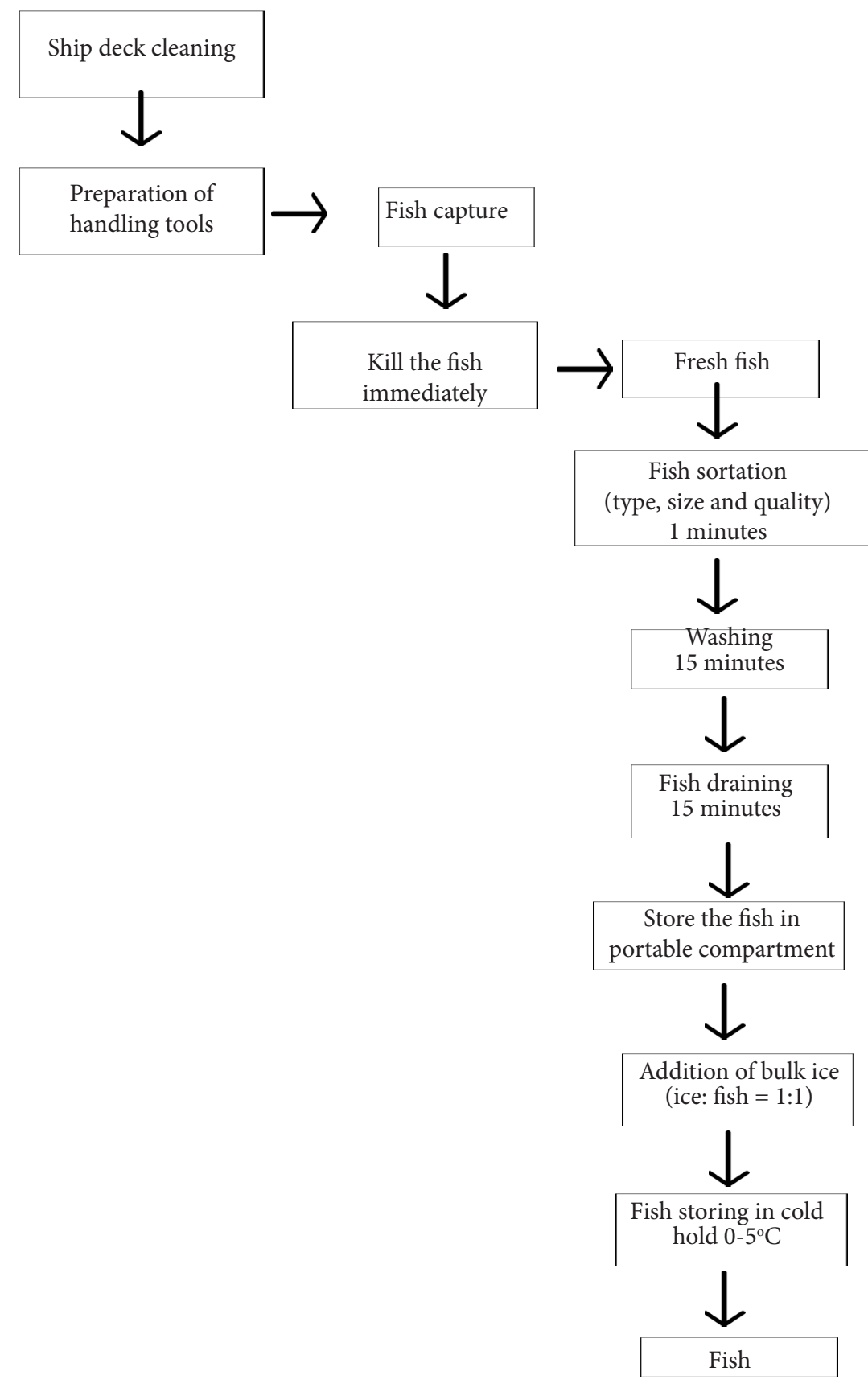

Figure 3 Improved fish handling system on board

menghambatkan aktivitas bakteri. Aktivitas enzim dan mikroorganisme pembusuk dapat terganggu oleh penggunaan suhu rendah $0-6^{\circ} \mathrm{C}$. Hal ini juga memengaruhi aktivitas bakteri setelah post rigor mortis berlangsung dan pembentukan basa volatile nitrogen karena reaksi kimia (Clucas dan Ward (1996). Gram dan Dalgaard (2002) menjelaskan bahwa pertumbuhan mikroba pada ikan dapat terhambat oleh adanya penggunaan suhu yang rendah.

\section{Penanganan Ikan Cakalang di Pusat Pendaratan Ikan}

Teknik penanganan oleh nelayan di pusat pendaratan ikan harus dilakukan dengan baik dan benar serta hati-hati, sehingga kualitas dan mutu ikan tetap terjaga. Kapal tiba di pusat pendaratan ikan pada pukul $19.00 \mathrm{WIT}$, sehingga penanganan ikan dilakukan nelayan pada waktu malam. Proses pembongkaran ikan dari palka pendinginan dilakukan dan diletakkan di atas dok kapal. Pensortiran 
dilakukan sesuai dengan permintaan Perum Perikanan dan pengumpul tentang ukuran ikan. Penanganan ikan di pusat pendaratan ikan oleh nelayan antara lain :

a). Pembongkaran. Pembongkaran dilakukan oleh dua orang nelayan dengan cara masuk ke dalam palka pendinginan kemudian ikan diangkat dengan tangan dan dimasukkan ke dalam jaring yang turunkan oleh tiga orang nelayan di atas deck kapal. Nelayan yang bertugas melakukan proses pembongkaran ikan dalam palka pendinginan mengunakan sepatu, dan hal ini dapat menyebabkan ikan terinjak dan cacat fisik. Kerusakan yang terjadi akibat ikan yang cacat fisik akan mempercepat aktivitas bakteri dan menyebabkan penurunan mutu ikan.

b). Pencucian. Proses pencucian ikan dilakukan setelah ikan di atas dok kapal.

c). Penyortiran ikan. Penyortiran ikan dilakukan berdasarkan ukuran sesuai permintaan.

d). Ikan dimasukkan ke dalam loyang pengumpul/sibu-sibu.

Penanganan ikan di pusat pendaratan ikan belum sesuai dengan prosedur yang ada. Penanganan yang menjadi perhatian nelayan dipusat pendaratan ikan adalah hanya memikirkan bagaimana membongkar ikan dari dalam palka pendinginan dengan cepat, kemudian dimasukkan ke dalam loyang para pembeli tanpa memikirkan kebersihan lantai deck kapal dan suhu di sekitarnya. Menurut Amos (2007) pada saat ikan tiba di tempat pendaratan, ikan tidak boleh diletakkan di lantai. Praktik ini tidak higienis, selain itu terjadinya degradasi mutu ikan disebabkan oleh suhu lingkungan yang tinggi, penanganan yang kasar dan tidak higienis yang dapat menyebabkan pembusukan ikan akibat terkontaminasi. Faktor kebersihan sangat penting karena sebagian besar lokasi pendaratan tidak memiliki fasilitas sanitasi dan penanganan. Ikan yang sudah dibongkar harus segera ditimbang dan didinginkan secepatnya untuk menjaga suhu tetap $\left(0^{\circ} \mathrm{C}-4^{\circ} \mathrm{C}\right)$, sehingga dapat memperlambat laju pembusukan oleh bakteri dan aktivitas enzim.

Beberapa hal penting yang belum diperhatikan oleh nelayan antara lain fasilitas sarana dan prasarana, tempat untuk melakukan proses pencucian, penirisan, dan pensortiran. Menurut Adawyah (2007), sebelum ikan dinaikkan ke atas dek kapal perlu dilakukan pembersihan dek kapal dan peralatan yang akan digunakan untuk penanganan ikan. Dari hasil pengamatan di lapangan, maka dapat digambarkan sistem penanganan ikan oleh nelayan di pusat pendaratan ikan (Figure 4).

Hasil wawancara menunjukkan bahwa ikan yang mengalami cacat fisik sebesar 3\% dan yang kualitas baik $97 \%$. Ikan yang kualitas baik kemudian dilakukan pembagian, $80 \%$ dari ikan cakalang ukuran besar dijual kepada Perum Perikanan untuk diekspor, sedangkan $17 \%$ ikan yang berukuran sedang dan kecil dijual kepada pengumpul atau pedagang kecil, kemudian pedagang kecil langsung menjual ke konsumen. Semua hasil tangkapan para nelayan dijual kepada pengumpul atau pedagang kecil dengan harga yang sangat

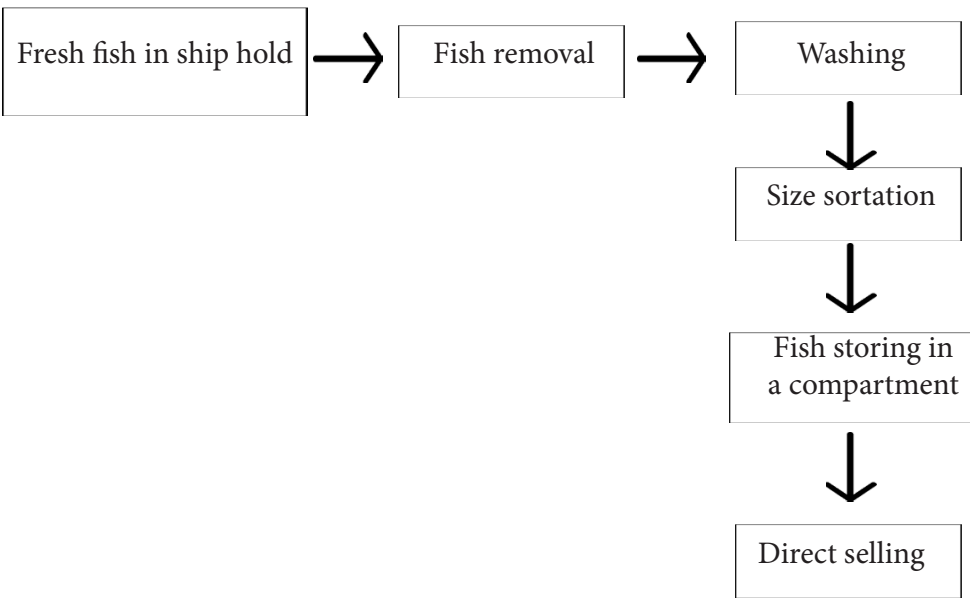

Figure 4 Fish handling at landing center 


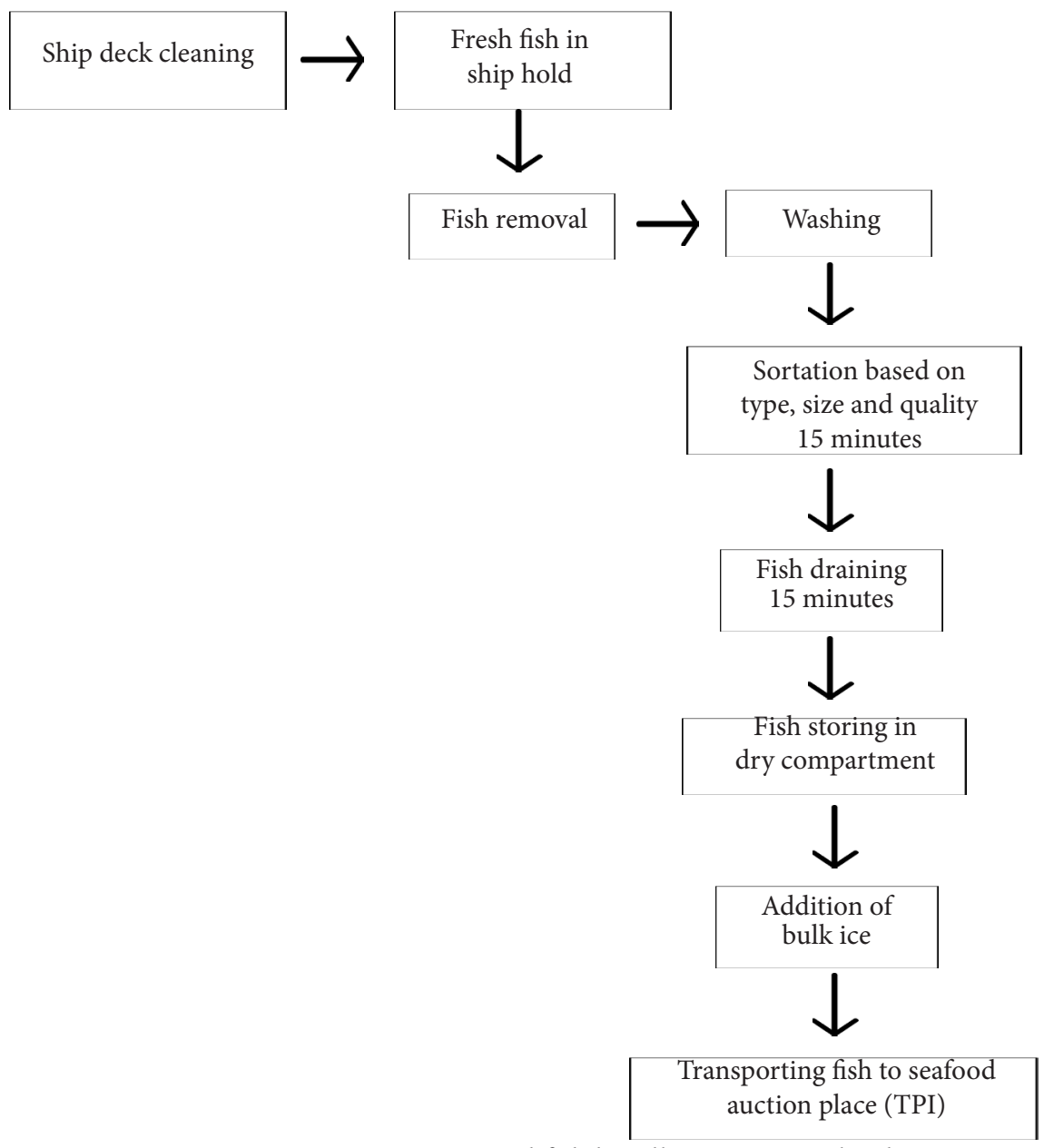

Figure 5 Improved fish handling system at landing center

Table 1 Organoleptic scores based on variation length of time

\begin{tabular}{ccc}
\hline No. & $\begin{array}{c}\text { Time in ship hold } \\
\text { (hour) }\end{array}$ & Organoleptic score \\
\hline 1 & 0 & 9.00 \\
2 & 2 & 8.87 \\
3 & 6 & 8.75 \\
4 & 12 & 8.68 \\
\hline
\end{tabular}

murah.

Penanganan ikan di pusat pendaratan ikan merupakan proses yang sangat penting diperhatikan untuk menjaga kualitas ikan tetap terjamin. Proses perbaikan di pusat pendaratan ikan untuk menjaga kesegaran dan kualitas ikan sampai di tangan konsumen dapat dilihat pada Figure 5.

\section{Perubahan Nilai Organoleptik}

Tingkat kesegaran ikan dapat ditentukan berdasarkan nilai organoleptik. Penentuan nilai organoleptik meliputi kriteria mata, lendir, insang, daging, bau, dan tekstur. Pengamatan karakteristik ikan menggunakan score sheet yang mengacu pada BSN (2006), sehingga dapat menentukan nilai penurunan mutu ikan. Hasil analisis varians menunjukkan bahwa proses pendinginan dan waktu penyimpanan secara signifikan mempengaruhi nilai organoleptik ikan (Sig.<0.01). Nilai rerata organoleptik ikan pada rentang waktu penyimpanan di palka mengalami penurunan (Table 1). 
Tabel ini menunjukkan bahwa pada 0 jam, nilai organoleptik 9 pada spesifikasi mata (cerah, bola mata menonjol, kornea jernih), insang (warna merah cemerlang, tanpa lendir), lendir (lapisan lendir jernih, transparan, mengkilat cerah), daging (sayatan daging sangat cemerlang, spesifik jenis, tidak ada pemerahan), bau (bau sangat segar, spesifik jenis), dan tekstur (padat, elastik bila ditekan dengan jari, sulit menyobek daging dari tulang belakang) (BSN 2006). Awal pengamatan organoleptik ikan sesaat setelah ditangkap, terlihat jelas bahwa baik mata, lendir, insang, daging, bau, dan tekstur ikan memiliki nilai kesegaran yang tinggi.

Waktu penyimpanan 2 jam dan 6 jam terjadi penurunan nilai rata-rata organoleptik masing-masing dengan nilai 8,87 dan 8,75 , ikan masih segar tetapi tidak seperti pada waktu 0 jam. Selanjutnya pada waktu penyimpanan 12 jam di palka saat ikan tiba di tempat pendaratan ikan terjadi penurunan lagi sebesar 8,68. Hal ini menunjukkan bahwa terjadi penurunan nilai organoleptik sesaat setelah ikan mati dengan nilai 9. Selama proses penyimpanan ikan dalam es, akan terjadi penurunan nilai organoleptik dan tekstur (Andersen et al. 1995; Sveinsdottir et al. 2002). Menurut Munandar et al. (2009) penilaian organoleptik merupakan rata-rata nilai karakteristik untuk menentukan tingkat kesegaran ikan yang meliputi kenampakan mata, warna insang, bau dan tekstur. Ikan yang telah busuk, memiliki mata cekung serta lebih keruh, warna insang merah kusam dan berlendir, bau amoniak dan asam, tekstur lunak dan kurang elastis.

\section{KESIMPULAN}

Cara penanganan ikan oleh nelayan menunjukkannilaiorganoleptikyangmengalami penurunan seiring dengan waktu penyimpanan di palka. Perbaikan cara penanganan ikan di atas kapal perlu dilakukan seperti proses mematikan ikan dengan segera sesaat setelah ikan ditangkap, mencegah agar ikan tidak meronta/menggelepar agar ikan tidak stress sehingga tidak kehilangan kandungan glikogen, dan penanganan pendinginan yang cepat oleh ABK yang khusus menangani proses penyimpanan ikan di dalam palka setelah proses penangkapan. Penanganan di pusat pendaratan ikan juga perlu diperhatikan seperti proses pembongkaran ikan di dalam palka dengan baik dan proses pendinginan tetap dilakukan untuk mengatasi penurunan kualitas ikan, sehingga ikan tetap segar sampai dikonsumsi.

\section{DAFTAR PUSTAKA}

Adawyah R. 2007. Pengolahan dan Pengawetan Ikan. Jakarta (ID): Bumi Aksara.

Akande G, Diei-Ouadi Y. 2010. Post-Harvest Losses in Small-scale Fisheries-Case Studies in Five sub-Saharan African Countries. Rome: FAO Fisheries and Aquaculture Tech.

Amos. 2007. Analysis of quality deterioration at critical steps/points in fish handling in Uganda and Iceland and suggestions for improvement. Final Project 2007. UNUFisheries Training Programme Uganda.

Andersen UB, Thomassen MS, Rora AMB. 1995. Texture properties of farmed Atlantic salmon (Salmo salar): Influence of storage time on ice and smelt age. In: Andersen, U.B (ed.). Measurements of texture quality in farmed Atlantic salmon (Salmo salar) and Rainbow trout (Oncorhynchus mykiss) (III). [Doctor Scientiarum Thesis]. Norway (Eur): Agricultural University of Norway.

[BSN] Badan Standardisasi Nasional. 2006. Uji Organoleptik Ikan Segar. SNI 01-23462006. Jakarta (ID): Badan Standardisasi Nasional.

Clucas IJ, Ward AR. 1996. Post harvest fisheries development: a guide handling, preservation, processing and quality. (UK): Natural Resources Institute.

Deni S. 2015. Karakteristik mutu ikan selama penanganan pada kapal KM. Cakalang. Jurnal Ilmiah Agribisnis Dan Perikanan. 8(2): 72-80.

Gram L, Dalgaard P. 2002. Fish spoilage bacteria - problems and solutions. Current Opinion in Biotechnology. 13: 262-266. 
Metusalach, Kasmiati, Fahrul, Jaya I. 2014. Pengaruh cara penangkapan, fasilitas penanganan dan cara penanganan ikan terhadap kualitas ikan yang dihasilkan. Jurnal IPTEKS PSP 1(1): 40-52.

Munandar A, Nurjannah, Nurimala. 2009. Kemunduran mutu ikan nila (Oreochromis niloticus) pada penyimpanan suhu rendah dengan perlakuan cara kematian dan penyiangan. Jurnal Teknologi Pengolahan Hasil Perikanan Indonesia. 12(2): 88-101.

Murniyati AS, Sunarman. 2000. Pendinginan, Pembekuan, Pengawetan Ikan. Yogyakarta (ID): Kanisius.

Olodosu, Ajayai RN, George FOA, Obasa SO, Bankole MO. 2011. Bacterial load, composition and succession in the African catfish, Clarias gariepinus held at ambient temperatures. Journal Researcher University Ota Ogun State Nigeria. 7(3):67-73.

Quang NH. 2005. Guidelines for handling and preservation of fresh fish for further processing in Vietnam. Iceland (Eur): The United Nation University Fisheries Training Programme.

Starling E, Diver G. 2005. The Australian Tuna Handling Manual: A Practical Guide for Industry. Queensland (AU): Seafood Service Australia.
Susanto E, Agustini TW, Swastawati F, Surti T, Fahmi AS, Albar MF, Nafis MK. 2011. Pemanfaatan bahan alami untuk memperpanjang umur simpan ikan kembung (Rastrelliger neglectus). Jurnal Perikanan. 13(2): 60-69.

Sveinsdottir K, Martinsdottir E, Hyldig G, Jorgensen B, Kristbergsson K. 2002. Application of quality index method (QIM) scheme in shelf-life study of farmed Atlantic salmon (Salmo salar). Journal Food Science. 67:1570-1579.

Tumonda S, Mewengkang HW, Timbowo SM. 2017. Kajian mutu ikan cakalang (Katsuwonus pelamis L ) asap terhadap nilai kadar air dan $\mathrm{pH}$ selama penyimpanan. Jurnal Media Teknologi Hasil Perikanan. 5(2): 64-68.

Wibowo S, Yunizal. 1998. Penanganan Ikan Segar. Instalasi Penelitian Perikanan Laut Slipi. Balai Penelitian Perikanan Laut. Jakarta (ID): Pusat Penelitian dan Pengembangan Perikanan.

Widiastuti I, Putro S. 2010. Analisis mutu ikan tuna selama lepas tangkap. Jurnal Maspari, 1:22-29.

[WWF] World Wide Fund for Nature. 2015. Perikanan cakalang dengan pancing pole and line (Huhate). Seri Panduan Perikanan Skala Kecil. Jakarta (ID): WWF-Indonesia. 